$\begin{array}{ll}\text { Research Square } & \text { Preprints are preliminary reports that have not undergone peer review. } \\ \text { They should not be considered conclusive, used to inform clinical practice, } \\ \text { or referenced by the media as validated information. }\end{array}$

\title{
Hydrothermal Assisted Biogenic Synthesis of Silver Nanoparticles And Their Anticandidal Activity On Virulent Candida Isolates From COVID-19 Patients
}

\author{
Fatma 0 Khalil \\ National Liver Institute, Menoufia University \\ Enas M. Ghonaim \\ National Liver Institute, Menoufia University \\ Shimaa Abed El-sattar \\ National Liver Institute, Menoufia University \\ Sally W. Elkhadry \\ National Liver Institute, Menoufia University \\ Hala El-Refai \\ National Liver Institute, Menoufia University \\ Muhammad Babar Taj ( $\nabla$ dr.taj@iub.edu.pk) \\ The Islamia University Bahawalpur \\ Omar Makram Ali \\ Turabah University College, Taif University \\ Ahmed Salah A. Elgawad \\ National Liver Institute, Menoufia University Hospital \\ Heba Alshater \\ Menoufia University Hospital, Menoufia University
}

\section{Research Article}

Keywords: antifungal potential, cytotoxicity properties, green chemistry, silver nanoparticles, covid-19 samples

Posted Date: December 29th, 2021

DOI: https://doi.org/10.21203/rs.3.rs-1203202/v1

License: (c) (i) This work is licensed under a Creative Commons Attribution 4.0 International License. Read Full License 


\section{Abstract}

Till now the exact mechanism and effect of biogenic silver nanoparticles on fungus is an indefinable question. To focus on this issue, we prepared hydrothermal assisted thyme coated silver nanoparticles (T/AgNPs) and their toxic effect on Candida isolates is described. The role of thyme (Thymus Vulgaris) in the reduction of silver ions and stabilization of T/AgNPs are estimated by Fourier transforms infrared spectroscopy, structure and size of present silver nanoparticles were detected via atomic force microscopy as well as high-resolution transmission electron microscopy. The biological activity of T/AgNPs was observed against Candida isolates from COVID-19 Patients. Testing of virulence of Candida species using Multiplex PCR. T/AgNPs proved highly effective against Candida albicans, Candida kruzei, Candida glabrata and MIC values ranging from 156.25 to $1,250 \mu \mathrm{mg} / \mathrm{mL}$ and MFC values ranging from 312.5 to $5,000 \mu \mathrm{g} / \mathrm{mL}$. The structural and morphological modifications due to T/AgNPs on Candida albicans were detected by TEM. It was highly observed that when Candida albicans cells were subjected to 50 and $100 \mu \mathrm{g} / \mathrm{mL} \mathrm{T} / \mathrm{AgNPs}$, a remarkable change in the cell wall and cell membrane was observed.

\section{Introduction}

The severe acute respiratory syndrome coronavirus 2 (SARS-CoV-2) is the primary infectious agent of Coronavirus Disease 2019 (COVID-19), a rapidly spreading pneumonia[1]. It is confronting the global public health system ${ }^{2}$. SARS-CoV-2 infects any age with a high impact on the elder people other than SARS-CoV and MERS-CoV ${ }^{3}$. Aside from the pathogenicity of SARS-CoV-2, microbial infections play a crucial role in the occurrence as well as the progression of SARS-CoV-2 infection by making a diagnosis, prognosis, and treatment of COVID-19 more difficult, as well as increasing illness symptoms and mortality ${ }^{2}$. Candida strains have been reported in the skin and mucosal dwellers that cause a variety of devastating diseases in immunosuppressed individuals and those who are susceptible ${ }^{4}$. Candida species possess numerous virulence factors, including exoenzymes like phospholipase as well as protease, or the capacity to generate the germ tubes and cling to buccal epithelial cells, that aid in the adherence as well as the intrusion of these organisms through the cell membrane, malfunctioning or rupturing ${ }^{5}$. The improper handling of antimicrobial drugs may enhance the prevalence of drug-resistant pathogens[2]. A major cause for the failure of antifungal treatment is low penetration potential to the infection site as well as their side effects[3].

Nanotechnology is one of the promising areas of science that has shown its impact on all scientific fields equally[4,5]. Nanosized materials, having a size of 20-100 nm, have attracted the attention of researchers because of their propitious characteristics[6]. Engineered silver nanoparticles (AgNPs) have shown their outstanding applications in food-related fields owing to their remarkable antifungal activities[7,8] and are widely applicable in the biomedical field like cancer photodynamic therapy, biomedical sensing, molecular imaging as well as drug delivery[9]. Synthesis of nanoparticles via green strategy such as by using plant extract[10], enzymes, phytochemicals etc are preferred mostly as compared to chemically manufactured nanosized material owing to overcome its toxic effect on the environment and living beings[11].

Thymus vulgaris L. plant has tremendous medical applications as it was used previously to treat various diseases like stiffening of arteries, urinary tract infections, dyspepsia, pneumonia, respiratory disorders (asthma, bronchitis, or cough), toothache, endocarditis[12-14] and septicaemia due to the presence of biochemical in it and it gains the status of the General Recognized as Safe (GRAS) defined by Food and Drug Administration (FDA)[15]. Thymol in Thymus vulgaris L. can destroy the cell membrane of microorganisms[16-18].

In most antifungal treatments, the main biological resistance for drug diffusion is the formation of biofilm that is formed by aggregation of Candida albicans[19,20]. Drug diffusion decreases due to the formation of biofilm that enhances the cell viscosity[21,22]. The exact mechanism for antifungal treatment is still unknown for thyme coated silver nanoparticles. The present study aims to develop a low cost sustainable hrdrothermal method without addition of any base and with minimum invovement of energy to explore the application and effect of T/AgNPs on membrane damage against Candida isolates from Covid-19 patients.

\section{Materials And Methods}

This is a cross-sectional study done using fungal isolates from COVID-19 patients admitted in patients of Menoufia Faculty of Medicine, Menoufia University hospital after patients consent and approval of Research Ethics Committee of faculty of medicine, Menoufia University (IRB No.

312021/FORE8). Fungal identification Antifungal testing and molecular detection of virulence factors were done in Microbiological laboratory, National liver Institute, Menoufia University. All chemicals as well as solvents were of analytical grade and were not purified further.

\subsection{Plant material}

The Thymus vulgaris plant was collected from Egypt. The plant was distinguished at the office of Botany, Faculty of Science, El-Menoufia University, Shebin El-Kom, Egypt where voucher examples were stored.

\subsection{Preparation of plant extract}

Fresh plant leaves were steeped in 70 percent ethanol/water $(100 \mathrm{ml})$ at room temperature for 7 days after being cleaned with tap water and finally with deionized water. It was then filtered by utilizing Whatman filter paper no. 1 The extract was then warmed to 4 degrees Celsius and stored for future use.

\subsection{Synthesis of silver nanoparticles}


Thyme loaded silver nanoparticles were synthesized by modified hydrothermal method[23]. A $25 \mathrm{ml}$ of $0.25 \mathrm{M}$ silver nitrate solution was mixed with 25 $\mathrm{ml}$ of plant extract and stirred at $35^{\circ} \mathrm{C}$ for $1 \mathrm{~h}$. This solution mixture was transferred into Teflon lined sealed stainless-steel autoclaves and kept in a hydrothermal oven at a temperature of $150{ }^{\circ} \mathrm{C}$ for $1.5 \mathrm{~h}$. Then the contents allowed to cool to room temperature. Pure dark brown colored T/AgNPs were collected by centrifugation at $5000 \mathrm{rpm}$ for 10 minutes. The T/AgNPs were dried in oven at $60{ }^{\circ} \mathrm{C}$ for $4 \mathrm{~h}$, ground, and preserved in airtight bottle (Figure 1).

\subsection{Characterization of silver nanoparticles}

The analysis was carried at National Research Centre Cairo Egypt. A Jasco dual-beam spectrophotometer was used to record the UV-vis spectroscopy estimates (model UV-VIS-NIR 570) operated at a resolution of $2 \mathrm{~nm}$. FTIR measurements were recorded on Perkin Elmer Inc ranging from $4000 \mathrm{~nm}$ to $650 \mathrm{~nm}$. Morphological ponders were employed utilizing high-resolution transmission electron microscopy (HRTEM). The HRTEM images were gotten by a JEOL-JEM-2100 version and an atomic force microscope (AFM) was used to determine surface topography and roughness profiles of Nanomaterials using Model 5600LS manufactured by Agilent technology company in the USA. The biological study was implemented in the National Liver Institute, Menoufia University during the period from May 2020 to February 2021 on different samples isolated from COVID-19 patients. The samples were inoculated on Sabrouds dextrose agar( HiMedia, India) and colonies identified by Gram staining, morphology on cornmeal agar, germ tube tests, and chromogenic medium (HiMedia, Mumbai, India), and further identification and antifungal sensitivity were done by the VITEK-2 Yeast identification and AST card (BioMé rieux).

\subsection{Biological activities}

\subsubsection{DNA extraction}

The QIAamp DNA Mini kit (Qiagen, Germany, $\mathrm{GmbH}$ ) was used to isolate DNA from samples, with certain changes based on the manufacturer's instructions. A $200 \mu$ l sample suspension was incubated at $56^{\circ} \mathrm{C}$ for 10 minutes with $10 \mu$ proteinase $\mathrm{K}$ and $200 \mu$ lysis buffer. Following that, 200 microliters of 100 percent ethanol were poured over the lysate. After that, a centrifuge was used to separate the solution. The nucleic acid was extracted with $100 \mu$ l of the kit's elution buffer.

\subsubsection{PCR amplification}

Oligonucleotide Primer: The primers used were provided by Metabion (Germany) and are listed in (Table 1). A $25 \mu$ reaction including $12.5 \mu$ l of EmeraldAmp Max PCR Master Mix (Takara, Japan), $1 \mu$ l of each primer at 20 pmol concentration, $5.5 \mu$ l of water, and $5 \mu$ l of DNA template was used to test the primers. An Applied biosystems 2720 thermal cycler was used to carry out the reaction.

Table 1. Primers sequences, target genes, amplicon sizes and cycling conditions.

\begin{tabular}{|c|c|c|c|c|c|c|c|c|}
\hline \multirow{2}{*}{$\begin{array}{l}\text { Target } \\
\text { gene }\end{array}$} & \multirow[t]{2}{*}{ Primers sequences } & \multirow{2}{*}{$\begin{array}{l}\text { Amplified } \\
\text { segment } \\
\text { (bp) }\end{array}$} & \multirow{2}{*}{$\begin{array}{l}\text { Primary } \\
\text { denaturation }\end{array}$} & \multicolumn{3}{|c|}{ Amplification (35 cycles) } & \multirow{2}{*}{$\begin{array}{l}\text { Final } \\
\text { extension }\end{array}$} & \multirow[t]{2}{*}{ Reference } \\
\hline & & & & $\begin{array}{l}\text { Secondary } \\
\text { denaturation }\end{array}$ & Annealing & Extension & & \\
\hline \multirow[t]{2}{*}{$A L S 3$} & CTGGACCACCAGGAAACACT & \multirow[t]{2}{*}{122} & $94^{\circ} \mathrm{C}$ & $94^{\circ} \mathrm{C}$ & $60^{\circ} \mathrm{C}$ & $72^{\circ} \mathrm{C}$ & $72^{\circ} \mathrm{C}$ & \multirow{4}{*}{$\begin{array}{l}\text { Tsang et } \\
\text { al., } 2012 \\
\text { [24] }\end{array}$} \\
\hline & ACCTGGAGGAGCAGTGAAAG & & $5 \mathrm{~min}$. & $30 \mathrm{sec}$. & 30 sec. & $30 \mathrm{sec}$. & $7 \mathrm{~min}$. & \\
\hline \multirow[t]{2}{*}{ RAS1 } & CCCAACTATTGAGGATTCTTATCGTAAA & \multirow[t]{2}{*}{106} & $94^{\circ} \mathrm{C}$ & $94^{\circ} \mathrm{C}$ & $60^{\circ} \mathrm{C}$ & $72^{\circ} \mathrm{C}$ & $72^{\circ} \mathrm{C}$ & \\
\hline & TCTCATGGCCAGATATTCTTCTTG & & $5 \mathrm{~min}$. & $30 \mathrm{sec}$. & $30 \mathrm{sec}$. & $30 \mathrm{sec}$. & $7 \mathrm{~min}$. & \\
\hline \multirow[t]{2}{*}{ HYR1 } & CGTCAACCTGACTGTTACATC & \multirow[t]{2}{*}{243} & $94^{\circ} \mathrm{C}$ & $94^{\circ} \mathrm{C}$ & $55^{\circ} \mathrm{C}$ & $72^{\circ} \mathrm{C}$ & $72^{\circ} \mathrm{C}$ & \multirow{2}{*}{$\begin{array}{l}\text { Luo et al. } \\
2010 \text { [25] }\end{array}$} \\
\hline & TCTACGGTGGTATGTGGAAC & & $5 \mathrm{~min}$. & $30 \mathrm{sec}$. & $30 \mathrm{sec}$. & $30 \mathrm{sec}$. & $7 \mathrm{~min}$. & \\
\hline \multirow[t]{2}{*}{ SAP4 } & GCT CTT GCT ATT GCT TTA TTA & \multirow[t]{2}{*}{394} & $94^{\circ} \mathrm{C}$ & $94^{\circ} \mathrm{C}$ & $49^{\circ} \mathrm{C}$ & $72^{\circ} \mathrm{C}$ & $72^{\circ} \mathrm{C}$ & \multirow{2}{*}{$\begin{array}{l}\text { Sikora et } \\
\text { al., } 2011 \\
\text { [26] }\end{array}$} \\
\hline & TAG GAA CCG TTA TTC TTA CA & & $5 \mathrm{~min}$. & $30 \mathrm{sec}$. & $40 \mathrm{sec}$. & $40 \mathrm{sec}$. & 10 min. & \\
\hline
\end{tabular}

\subsubsection{Analysis of the PCR Products}

The PCR products were eluted out using $5 \mathrm{~V} / \mathrm{cm}$ gradients on a 1.5 percent agarose gel (Applichem, Germany, GmbH) in $1 \times$ TBE buffer at room temperature. $15 \mu \mathrm{l}$ of the products were inserted into each gel slot for analysis. The fragment sizes were determined using a general 100 bp ladder (Fermentas, Germany) as well as gelpilot 100 bp ladders. A gel documentation system (Alpha Innotech, Biometra) was used to photograph the gel, and the data was processed using computer software. (Table 3) lists the target genes, primer sequences cycle conditions and amplicon sizes, 
The antifungal effect of biosynthetic T/AgNPs was evaluated on virulent Candida. albicans and non-albicans isolates using the disc diffusion method

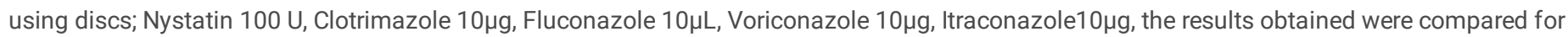
T/AgNPs formed by using the chemical strategy and Thymus vulgaris. The disk diffusion method shows the magnitude of the susceptibility of the virulent fungi. The Minimal Inhibitory concentrations (MICs) for fungi were identified as the low quantity at which there is no visible growth can be seen.

\subsubsection{Statistical Analysis}

The mean and standard error were used to express all the data. To determine the relationship between qualitative variables, the Chi-square test will be performed. When more than $25 \%$ of the cells have an anticipated count of less than 5 , the Fisher exact test will be applied for $2 \times 2$ qualitative variables. When comparing the mean and SD of two sets of quantitative normally distributed data, the Student T-test will be employed, whereas the Mann Whitney test will be used when the data is not normally distributed. When comparing three or more groups with quantitative normally distributed data, the oneway analysis of variance (ANOVA) test will be performed, whereas the Kruskal-Wallis test will be used when the data is not normally distributed. When the P-value is less than 0.05 , it is considered statistically significant.

\section{Results}

\subsection{UV-vis analysis}

The hydrothermal synthesis of T/AgNPs using Thymus vulgaris plant extract was detected by visual inspection of the fabricated samples in addition, to monitoring the UV-vis spectra. Alteration of color to yellowish-brown in aqueous solution confirmed the formation of silver nanoparticles[27]. It was observed the color change of colorless solution of silver nitrate to yellowish-brown after $10 \mathrm{~min}$ of the addition of extract sample owing to the preparation of silver nanoparticles and this was evaluated by using UV-vis spectrophotometer as depicted in (Figure 2). At the end of the reaction, the solution of silver nanoparticles was investigated for stability. It was observed that

nanoparticles were stable for a long time without being agglomerated. A small band at $438 \mathrm{~nm}$ was observed which appeared in the absorption spectra of the fabricated sample $(0.1 \mathrm{ml}$ sample). If the concentration of plant extract was increased, the band was positioned from $438 \mathrm{~nm}$ to $425 \mathrm{~nm}$.

This band was identified to the absorption by colloidal silver nanoparticles in the visible region $(380-450 \mathrm{~nm})$ because of the excitation of surface plasmon vibrations[28]. The intensity of peaks increased and this is an indication of the increase of concentration of silver nanoparticles[29]. In addition, it was observed that the shifting of the band to lower wavelength from maximum absorption wavelength indicated the formation of smallsized Ag nanoparticles with an increased amount of Thymus vulgaris. So, it is manifested that there is a successful reduction to silver nanoparticles using Thymus vulgaris extract.

\subsection{Fournier Infrared analysis (FTIR)}

The identification of biomolecules that are responsible for the reduction and stabilization of silver nanoparticles were detected by FTIR. Thymus vulgaris has a heavy amount of protein and is highly concentrated in amino acids[30]. FTIR measurements for Thymus vulgaris extract and reduced silver nanoparticles were depicted in (Figure 3). FTIR transmittance peak at $3357 \mathrm{~cm}^{-1}$ was detected for Thymus vulgaris extract, which was allotted to $\mathrm{OH}$ stretching vibration, which become narrow and shifted to the high region at $3267 \mathrm{~cm}^{-1}$. Other bands at 1700 and $1623 \mathrm{~cm}^{-1}$ were due to amide I and at $1443 \mathrm{~cm}^{-1}$ was assigned to amide II respectively and the peak at $1270 \mathrm{~cm}^{-1}$ corresponds to amide III[31-34].

The modification in structure is an indication that the reduction, as well as stabilization of silver nanoparticles, advanced through the coordination between the nitrogen atom of the amide group as well as silver ions. It was shown by FTIR measurements that the amide group of protein has a greater capacity to bind metal. The proteins play a significant role as a capping agent as well as preventing the aggregation of nanoparticles.

\subsection{High-resolution transmission electron microscopy (HRTEM) Analysis}

TEM measurements are proceeded to evaluate the particle size as well as size distribution for the fabricated nanoparticles. (Figure 4). shows HRTEM images registered from the drop coated HRTEM grid of the manufactured Ag nanoparticles. Nanoparticles with agglomeration and spherical shape were depicted in micrographs which are of course due to the aggregation of silver nanoparticles. It is clear the presence of a gap in T/AgNPs shown in the HRTEM images due to covering of Thymus vulgaris extract and at lower concentration of Thymus vulgaris extract, fewer molecules were present which deficient in to cover the nanoparticle surfaces leading to the expedition of the aggregation. At some level of Thymus vulgaris extract content, all the nanoparticles are loaded, therefore stabilization occurs. So, Thymus vulgaris extract is utilized defensive agents to prohibit the aggregation through interaction with initial nanoparticles. and this is in a good agreement explanation of UV-vis spectroscopy results, which is distinguished from welldispersed silver nanoparticles. The small particle size of T/AgNPs is detected from $19 \mathrm{~nm}$ to $25 \mathrm{~nm}$ which is due to the enhanced amount of plant extract. Moreover, the size distribution becomes narrower as the amount of Thymus vulgaris plant extract exceeds. From these results, it is concluded that the size of the formed nanoparticles becomes smaller, and the particle size distribution is amended as the quantity of the extract rises.

\subsection{Atomic force microscope (AFM) Analysis}

The atomic force of microscopy was utilized for the determination of morphology and agglomeration of silver nanoparticles using Thymus vulgaris extract as shown in (Figure 5). Individual particles, as well as clusters of particles, can also be identified with the AFM. Microscope pictures are crucial

Page $4 / 20$ 
in research and development initiatives, as well as when fixing quality control problems. The AFM allows for three-dimensional viewing. The vertical, or $Z$, axis resolution is restricted by the instrument's vibration environment, whereas the horizontal, or X-Y, axis resolution is limited by the diameter of the scanning tip. Agglomeration of silver nanoparticles biosynthesized on the surface.

\subsection{Antimicrobial activity}

The antifungal treatment was performed by determining the clear inhibition zone supplied with $0.031-0.5 \mathrm{mg} / \mathrm{mL}$ of silver nanoparticles. The development of the Candida population was observed to decrease by supplying $0.5 \mathrm{mg} / \mathrm{mL}$ of T/AgNPs (Figure 6). The greater inhibition zone (22 mm) was monitored for Candida albicans, The MICs value observed for T/AgNPs from $0.125-0.250 \mathrm{mg} / \mathrm{mL}$ against Candida and bacteria species while MBCs and MFCs value obtained was 0.250 and $0.5000 \mathrm{mg} / \mathrm{mL}$ respectively. In a present research T/AgNPs with MIC values ranging from 156.25 to $1,250 \mu \mathrm{g} / \mathrm{mL}$ and MFC values ranging from 312.5 to $5,000 \mu \mathrm{g} / \mathrm{mL}$ against Candida kruzei, Candida glabrata and Candida albicans. It was indicated from MIC and MFC values that T/AgNPs has a greater potential for anticandidal activity. Moreover, Different amount of T/AgNPs ranging from 62.5 to $1000 \mu \mathrm{g} / \mathrm{mL}$ was also applied to check the effect on the development of Candida tropicalis Candida famata and Candida albicans species, followed by decreased growth of candida species at all concentration of the sample. The Candida species growth increases rapidly in the dearth of T/AgNPs. However, when the high quantity of T/AgNPs from 500 to $1000 \mu \mathrm{g} / \mathrm{mL}$ was applied, the Candida cells growth was ceased. It has been shown from (Figure 6) that the growth inhibition of Candida cells was increased with an increased amount of T/AgNPs. The Minimal Inhibitory concentrations (MICs) for fungi were identified as the lowest quantity at which no visual growth was observed. The Minimum fungicidal concentration (MFC) $[35,36]$ was defined as the lowest drug concentration at which subcultures yielded negative findings or less than three colonies, indicating that $>99 \%$ of the original inoculum had died.

\subsection{Morphological and ultrastructural alteration caused by T/AgNPs}

The structural and morphological modifications due to T/AgNPs on Candida albicans were detected by TEM. It was detected that when Candida albicans cells were subjected to 50 and $100 \mu \mathrm{g} / \mathrm{mL}$ T/AgNPs, a remarkable change in the cell wall and cell membrane was observed (Figure 6). It was found from TEM analysis that T/AgNPs were adhered not only on the surface of the cell wall and membrane but also penetrate the cell and stored in the cytoplasm followed by the rupturing of the cell wall and destruction of the cytoplasmic membrane (Figures 6). The recent TEM analysis is in good agreement with the previous work on morphological analysis of the effects of T/AgNPs on Candida albicans. The exact Anticandidal mechanism of nanostructured material is not known. Kim et al studied that the cell membrane and cell wall of the Candida albicans species were destroyed by T/AgNPs due to the formation of "pits and holes" on the surface which prevents the process of budding and results in cell death. Gutierrez et al. [37] reported his work on antifungal activity of T/AgNPs due to inhibition of $\beta$-glucan synthase and structural modifications of cell wall which loss its proper functioning and followed by cell death. Furthermore, in other literature, it was reported that T/AgNPs enhance apoptosis in mitochondria, DNA, and nuclear fragmentation, phosphatidylserine externalization as well as the activation of metacaspases in Candida albicans and leads to cell destruction due to the build-up of intercellular ROS. Radhakrishnan et al studied that Candida albicans cell destruction is not only due to the accumulation of ROS but also the T/AgNPs affect the cellular microenvironment membrane fluidity, structure, and ultrastructure, cellular ergosterol levels, as well as fatty acid composition, particularly oleic acid, which is essential for hyphal morphogenesis

Candida albicans isolate resistant to antifungal agents; Nystatin $100 \mu \mathrm{g}$, miconazole $(10 \mu \mathrm{g})$, Clotrimazole $(50 \mu \mathrm{g})$, flucytosine $(25 \mu \mathrm{g})$ and sensitive to Fluconazole $(25 \mu \mathrm{g})$. taking subcultures on the middle plate showing that the Candida isolates in the are resistant to Thymus vulgaris alone (lower part) and sensitive to silver nitrate alone; the zone of inhibition increases on the addition of biologically active silver nitrate solution in the sabrouds agar plate on the right.

\subsection{High-resolution Transmission Electron Microscopy (HRTEM)}

To visualize the action of biologically active silver nitrate on Candida albicans isolates (Figures 8, 9,10 \& 11) After growth, the fungal cells were centrifuged as well as fixed with $2.5 \%$ glutaraldehyde as well as $4 \%$ paraformaldehyde (Sigma-Aldrich) and finally contrasted in the solution of $5 \%$ uranyl acetate. Dehydration was performed using acetone (Sigma-Aldrich). The samples were analyzed under a transmission electron microscope (Thermo Fisher Scientific, USA).

The sociodemographic features, clinical and laboratory data and prognosis of the studied patients with and without fungal growth are mentioned in (Table 2). Candida albicans isolates features as mentioned in (Table 3) regarding antifungal sensitivity and virulence factors. (Figures 12 and 13 ) show the effect of Thymus vulgaris alone and after union with silver nitrate particles on Candida albicans isolates in comparison to other antifungal agents.

Table 2. Demographic, clinical-laboratory data, and prognosis of patient's groups 


\begin{tabular}{|c|c|c|c|c|c|c|}
\hline & & Result & & Total & Test & $\mathrm{p}-$ \\
\hline & & $\begin{array}{l}\text { Patients without fungal } \\
\text { growth }\end{array}$ & $\begin{array}{l}\text { Patients with fungal } \\
\text { Growth }\end{array}$ & & & \\
\hline & & $\mathrm{N}=14$ & $\mathrm{~N}=46$ & & & \\
\hline Sex & Male & $964.3 \%$ & $3269.6 \%$ & $4168.3 \%$ & $X^{2}=0.138$ & 0.749 \\
\hline & Female & $535.7 \%$ & $1430.4 \%$ & $1931.7 \%$ & & \\
\hline Age & Mean \pm Std.Deviation & $50.93 \pm 6.866$ & $51.96 \pm 7.489$ & $51.72 \pm 7.305$ & $\mathrm{U}=0.315$ & 0.753 \\
\hline & N Median & 1452.00 & 4652.00 & 6052.00 & & \\
\hline & Minimum-Maximum & $33-60$ & 24- 66 & $24-66$ & & \\
\hline Sample & Ascitic & $0(0.0 \%)$ & $1(2.2 \%)$ & $1(1.7 \%)$ & $\mathrm{LR}=3.7$ & 0.589 \\
\hline & bedsore & $1(7.1 \%)$ & $2(4.3 \%)$ & $3(5.0 \%)$ & & \\
\hline & Blood & $7(50.0 \%)$ & $16(34.8 \%)$ & $23(38.3 \%)$ & & \\
\hline & cannula site & $0(0.0 \%)$ & $1(2.2 \%)$ & $1(1.7 \%)$ & & \\
\hline & sputum & $5(35.7 \%)$ & $15(32.6 \%)$ & $20(33.3 \%)$ & & \\
\hline & Urine & $1(7.1 \%)$ & $11(23.9 \%)$ & $12(20.0 \%)$ & & \\
\hline NasalSARSCOV2PCR & Negative & $0(0.0 \%)$ & 1 & 1 & Fisher $=0.31$ & 0.767 \\
\hline & Positive & $14(100.0 \%)$ & $2.2 \%$ & $1.7 \%$ & & \\
\hline & & & 45 & 59 & & \\
\hline & & & $97.8 \%$ & $98.3 \%$ & & \\
\hline RBS & Mean \pm & 107.29 & 119.09 & 116.33 & $\mathrm{U}=0.861$ & 0.39 \\
\hline & SD & 12.755 & 59.450 & 52.506 & & \\
\hline & $\mathrm{N}$ & 14 & 46 & 60 & & \\
\hline & Median & 102.00 & 101.00 & 102.00 & & \\
\hline & (Min- & 98 & 82 & 82 & & \\
\hline & Max) & 147 & 400 & 400 & & \\
\hline CRP & Mean \pm & 50.57 & 53.67 & 52.91 & $\mathrm{U}=0.195$ & 0.845 \\
\hline & SD & 36.091 & 41.095 & 39.633 & & \\
\hline & $\mathrm{N}$ & 14 & 43 & 57 & & \\
\hline & Median & 46.00 & 48.00 & 47.00 & & \\
\hline & (Min- & 12 & 8 & 8 & & \\
\hline & Max) & 140 & 225 & 225 & & \\
\hline CBC(WBCS) & Mean \pm & 7.014 & 7.941 & 7.725 & $U=2.258$ & $0.024^{\star}$ \\
\hline & SD & 5.7567 & 4.5884 & 4.8493 & & \\
\hline & N & 14 & 46 & 60 & & \\
\hline & Median & 4.150 & 6.450 & 6.250 & & \\
\hline & (Min- & 3.1 & 3.1 & 3.1 & & \\
\hline & Max) & 19.8 & 19.8 & 19.8 & & \\
\hline Lymphocytes & Mean $\pm S D$ & $68.186 \pm 160.9142$ & $21.843 \pm 12.0892$ & $32.657 \pm 78.7876$ & $U=1.19$ & 0.234 \\
\hline & N Median & 1425.550 & 4616.800 & 6018.250 & & \\
\hline & (Min-Max) & $6.0-625.0$ & $6.5-54.3$ & $6.0-625.0$ & & \\
\hline ESR & Mean $\pm S D$ & $47.71 \pm 30.139$ & $45.04 \pm 30.663$ & $45.67 \pm 30.308$ & $U=0.307$ & 0.759 \\
\hline & N Median & 1451.00 & 4640.00 & 6040.00 & & \\
\hline & (Min-Max) & $8-85$ & $5-110$ & $5-110$ & & \\
\hline
\end{tabular}

Page 6/20 


\begin{tabular}{|c|c|c|c|c|c|c|}
\hline \multirow[t]{3}{*}{ serum ferritin } & Mean $\pm S D$ & $542.93 \pm 231.288$ & $553.07 \pm 291.897$ & $550.70 \pm 277.113$ & $U=0.105$ & 0.916 \\
\hline & N Median & 14506.00 & 46519.00 & 60506.00 & & \\
\hline & (Min-Max) & $320-1150$ & $25-1150$ & $25-1150$ & & \\
\hline \multirow[t]{3}{*}{ D-Dimer } & Mean $\pm S D$ & $23.2857 \pm 80.22222$ & $8.6972 \pm 44.22143$ & $12.1012 \pm 54.29772$ & $U=0.74$ & 0.459 \\
\hline & N Median & 142.0000 & 462.0000 & 602.0000 & & \\
\hline & (Min-Max) & $1.00-302.00$ & $.00-302.00$ & $.00-302.00$ & & \\
\hline \multirow[t]{3}{*}{ LDH } & Mean $\pm S D$ & $543.64 \pm 186.578$ & $640.04 \pm 262.926$ & $617.55 \pm 249.173$ & $U=1.006$ & 0.315 \\
\hline & N Median & 14542.50 & 46654.00 & 60555.00 & & \\
\hline & (Min-Max) & $204-876$ & $204-1234$ & $204-1234$ & & \\
\hline \multirow[t]{2}{*}{ Prognosis } & Death & $00.0 \%$ & $48.7 \%$ & $46.7 \%$ & Fisher $=1.3$ & 0.564 \\
\hline & Recovery & $14100.0 \%$ & 42 91.3\% & $5693.3 \%$ & & \\
\hline
\end{tabular}

Table 3. The sociodemographic, laboratory, antifungal sensitivity, virulence factors in Candida albicans versus Candida non-albicans isolates 


\begin{tabular}{|c|c|c|c|c|c|c|}
\hline & & \multicolumn{2}{|l|}{ Candida } & \multirow[t]{3}{*}{ Total } & \multirow[t]{3}{*}{ Test } & \multirow[t]{3}{*}{ p-value } \\
\hline & & Candida albican & Candida non albican & & & \\
\hline & & $\mathrm{N}=33$ & $\mathrm{~N}=10$ & & & \\
\hline \multirow[t]{4}{*}{ Sex } & Male & 24 & 5 & 29 & $x^{2}=1.8$ & 0.179 \\
\hline & Female & $72.7 \%$ & $50.0 \%$ & $67.4 \%$ & & \\
\hline & & 9 & 5 & 14 & & \\
\hline & & $27.3 \%$ & $50.0 \%$ & $32.6 \%$ & & \\
\hline \multirow[t]{6}{*}{ Age } & Mean & 52.12 & 50.00 & 51.63 & $U=0.403$ & 0.702 \\
\hline & Std. Deviation & 5.830 & 11.776 & 7.512 & & \\
\hline & $\mathrm{N}$ & 33 & 10 & 43 & & \\
\hline & Median & 51.00 & 53.50 & 52.00 & & \\
\hline & Minimum & 43 & 24 & 24 & & \\
\hline & Maximum & 66 & 63 & 66 & & \\
\hline \multirow[t]{12}{*}{ Sample } & ascitic & 1 & 0 & 1 & $\mathrm{LH}=2.7$ & 0.745 \\
\hline & bedsore & $3.0 \%$ & $0.0 \%$ & $2.3 \%$ & & \\
\hline & Blood & 2 & 0 & 2 & & \\
\hline & cannula site & $6.1 \%$ & $0.0 \%$ & $4.7 \%$ & & \\
\hline & sputum & 10 & 4 & 14 & & \\
\hline & Urine & $30.3 \%$ & $40.0 \%$ & $32.6 \%$ & & \\
\hline & & 1 & 0 & 1 & & \\
\hline & & $3.0 \%$ & $0.0 \%$ & $2.3 \%$ & & \\
\hline & & 10 & 4 & 14 & & \\
\hline & & $30.3 \%$ & $40.0 \%$ & $32.6 \%$ & & \\
\hline & & 9 & 2 & 11 & & \\
\hline & & $27.3 \%$ & $20.0 \%$ & $25.6 \%$ & & \\
\hline \multirow[t]{4}{*}{ CORAD } & 4 & 31 & 9 & 40 & Fisher $=0.184$ & 0.558 \\
\hline & 5 & $93.9 \%$ & $90.0 \%$ & $93.0 \%$ & & \\
\hline & & 2 & 1 & 3 & & \\
\hline & & $6.1 \%$ & $10.0 \%$ & $7.0 \%$ & & \\
\hline \multirow[t]{4}{*}{ NasalSARSCOV2PCR } & Negative & 1 & 0 & 1 & Fisher $=0.31$ & 1.00 \\
\hline & Positive & $3.0 \%$ & $0.0 \%$ & $2.3 \%$ & & \\
\hline & & 32 & 10 & 42 & & \\
\hline & & $97.0 \%$ & $100.0 \%$ & $97.7 \%$ & & \\
\hline \multirow[t]{6}{*}{ RBS } & Mean \pm & 118.00 & 113.60 & 116.98 & $\mathrm{U}=0.202$ & 0.840 \\
\hline & SD & 62.068 & 40.716 & 57.393 & & \\
\hline & $\mathrm{N}$ & 33 & 10 & 43 & & \\
\hline & Median & 100.00 & 106.00 & 102.00 & & \\
\hline & (Min- & 87 & 82 & 82 & & \\
\hline & Max) & 400 & 225 & 400 & & \\
\hline \multirow[t]{4}{*}{ CRP } & Mean \pm & 55.69 & 52.67 & 55.02 & $\mathrm{U}=0.315$ & 0.752 \\
\hline & SD & 44.397 & 31.149 & 41.512 & & \\
\hline & $\mathrm{N}$ & 32 & 9 & 41 & & \\
\hline & Median & 44.00 & 50.00 & 48.00 & & \\
\hline
\end{tabular}




\begin{tabular}{|c|c|c|c|c|c|c|}
\hline & \multirow{2}{*}{$\begin{array}{l}\text { (Min- } \\
\text { Max) }\end{array}$} & \multirow{2}{*}{$\begin{array}{l}8 \\
225\end{array}$} & \multirow{2}{*}{$\begin{array}{l}12 \\
125\end{array}$} & \multicolumn{3}{|l|}{8} \\
\hline & & & & 225 & & \\
\hline \multirow[t]{6}{*}{ CBC(WBCS) } & Mean \pm & 7.679 & 9.440 & 8.088 & $U=1.497$ & 0.134 \\
\hline & SD & 4.6798 & 4.7984 & 4.7103 & & \\
\hline & $\mathrm{N}$ & 33 & 10 & 43 & & \\
\hline & Median & 6.400 & 6.850 & 6.500 & & \\
\hline & (Min- & 3.1 & 5.4 & 3.1 & & \\
\hline & Max) & 19.8 & 18.0 & 19.8 & & \\
\hline \multirow[t]{6}{*}{ Lymphocytes } & Mean士 & 22.339 & 16.700 & 21.028 & $\mathrm{U}=0.792$ & 0.428 \\
\hline & SD & 12.8928 & 6.6663 & 11.9155 & & \\
\hline & $\mathrm{N}$ & 33 & 10 & 43 & & \\
\hline & Median & 17.200 & 15.000 & 16.400 & & \\
\hline & (Min- & 6.5 & 7.0 & 6.5 & & \\
\hline & Max) & 54.3 & 31.0 & 54.3 & & \\
\hline \multirow[t]{6}{*}{ ESR } & Mean \pm & 46.67 & 44.60 & 46.19 & $\mathrm{U}=0.217$ & 0.829 \\
\hline & SD & 31.075 & 29.710 & 30.425 & & \\
\hline & $\mathrm{N}$ & 33 & 10 & 43 & & \\
\hline & Median & 40.00 & 35.00 & 40.00 & & \\
\hline & (Min- & 5 & 6 & 5 & & \\
\hline & Max) & 110 & 100 & 110 & & \\
\hline \multirow[t]{6}{*}{ serum ferritin } & Mean \pm & 569.61 & 514.80 & 556.86 & $\mathrm{U}=0.374$ & 0.708 \\
\hline & SD & 286.640 & 285.329 & 283.891 & & \\
\hline & $\mathrm{N}$ & 33 & 10 & 43 & & \\
\hline & Median & 540.00 & 519.00 & 540.00 & & \\
\hline & (Min- & 98 & 25 & 25 & & \\
\hline & Max) & 1150 & 1150 & 1150 & & \\
\hline \multirow[t]{6}{*}{ D-Dimer } & Mean \pm & 11.3052 & 2.2000 & 9.1877 & $U=0.207$ & 0.836 \\
\hline & SD & 52.19852 & 1.03280 & 45.73104 & & \\
\hline & $\mathrm{N}$ & 33 & 10 & 43 & & \\
\hline & Median & 2.0000 & 2.0000 & 2.0000 & & \\
\hline & (Min- & .00 & .00 & .00 & & \\
\hline & Max) & 302.00 & 4.00 & 302.00 & & \\
\hline \multirow[t]{6}{*}{ LDH } & Mean \pm & 645.88 & 703.10 & 659.19 & $U=0.504$ & 0.615 \\
\hline & SD & 252.923 & 292.207 & 260.066 & & \\
\hline & $\mathrm{N}$ & 33 & 10 & 43 & & \\
\hline & Median & 663.00 & 732.50 & 663.00 & & \\
\hline & (Min- & 204 & 220 & 204 & & \\
\hline & Max) & 1234 & 1038 & 1234 & & \\
\hline \multirow[t]{4}{*}{ Fluconazole } & $\mathrm{S}$ & 20 & 3 & 23 & $X 2=2.89$ & 0.089 \\
\hline & $\mathrm{R}$ & $60.6 \%$ & $30.0 \%$ & $53.5 \%$ & & \\
\hline & & 13 & 7 & 20 & & \\
\hline & & $39.4 \%$ & $70.0 \%$ & $46.5 \%$ & & \\
\hline Miconazole & $S$ & 19 & 2 & 21 & $X 2=4.337$ & 0.037 * \\
\hline
\end{tabular}

Page 9/20 


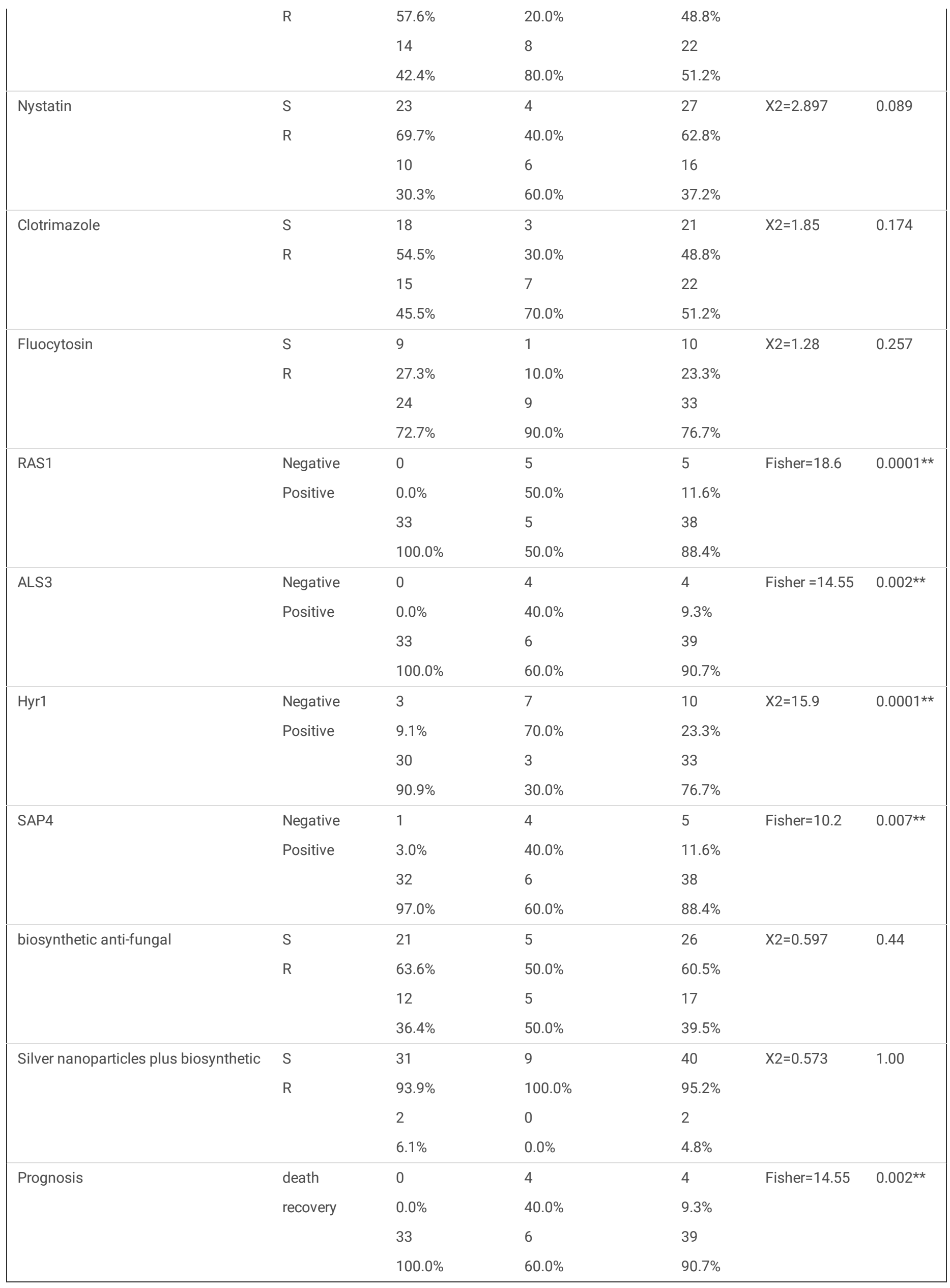


Candida species, Aspergillus, and P. jirovecii infections were found in critically unwell COVID-19 patients. parenteral feeding, broad-spectrum antibacterial medication, mechanical ventilation, indwelling central venous as well as bladder catheters, lymphopenia, comorbidities, older age, and corticosteroids ${ }^{14}$ are all prevalent in COVID-19 patients admitted to the ICU. The goal of this study was to characterise fungal infection in COVID-19 patients while also investigating the antifungal effects of silver nitrate biosynthesized by Thymus vulgaris.

\section{Discussion}

The hydrothermal method has been adopted for the biogenic synthesis of silver nanoparticles. The main advantage of this method is that it can produce a bulk amount of silver nanoparticles and the efficiency of this procedure is very much high as compared to other known methods. The synthesized T/AgNPs have been well characterized by various techniques. To check the anticandidal activity, forty-six fungal isolates were obtained from different specimens of 60 COVID-19 inpatients; 33 were Candida albicans, 10 Candida non-albicans isolates (2 Candida famata, 4 Candida galabrata, 2 Candida krusei, and 2 Candida tropicalis). It has been reported that bacteria species and fungi are considered co-infections in critically ill patients with COVID-19, which increases its morbidity and mortality15. Numerous strains of Candida also have been identified as unique pathogens from COVID-19 patients' pulmonary specimens (TA, BAL as well as BAS) and recognized as a source of co-infections [38] and the frequency of fungal co-infection was significantly greater than previously reported [38].

It is found that Candida albicans isolates were highly virulent as $90.7 \%$ of isolates had ALS3 and $76.7 \%$ had the Hyr1 gene. Hyr1 and Als3 are hyphaspecific genes and the hyphal regulator RAS1 is related to adhesion and increase fungal pathogenicity[39]. The RAS1 was prevalent in 88.4\%. Ras signalling is crucial to the integration of environmental cues with morphogenesis and virulence[40]. The SAP4 gene was detected in 88.4 percent of Candida isolates in this investigation. Twenty secreted aspartic proteinase (Sap) isoenzymes are responsible for Candida sppproteinase's activity. The sap is encoded by ten genes in Candida, SAP1-10. Collagen, keratin, and mucus, among other epithelial and mucosal barrier proteins, degrade in the presence of sap[41].

The Candida isolates displayed miconazole and clotrimazole resistance in $51.2 \%$ of isolates and $100 \%$ of aspergillus isolates. Flucytosine resistance occurred in $76.7 \%$, nystatin resistance in $37.2 \%$ and fluconazole resistance in $46.5 \%$ of isolates. Many researchers have demonstrated that lower Candida susceptibility is strongly related to previous antifungal exposures and an unsuitable prior course of antifungal therapy, according to Aldardeer, N. et al, 2020[42] and Shan, D.N., 2012 mention similar results with other authors[43]-[44]. Fluconazole treatment was discovered to be a potential risk for gene mutation and overexposure, which leads to long term fluconazole-resistant $C$. parapsilosis[45]. Plant extracts, which contain biomolecules and plant metabolites including flavonoids, tannins, and terpenoids, polyphenols as well as algae and fungal metabolites, have special qualities that allow them to be employed as a reducing and capping agent for the manufacture of pharmaceuticals and stabilisation of nanoparticles (NPs) in a variety of fields, including biomedical, pharmaceutical, and food industries[46]. In the current study, Thymus vulgaris derived silver nanoparticles showed a significant antifungal effect with a decrease in the number of resistant isolates than known antifungal fluconazole, miconazole, nystatin, clotrimazole and flucytosine (P-value <0.05). This finding was in line with Mohammadi, M., et al., 2019, who found that Ag NPs manufactured from thyme extract have no cytotoxicity at concentrations below $3.5 \mathrm{ppm}$, making them a viable alternative to Fluconazole for treating superficial fungal infections[47]. Similar results were obtained by Anjugam, M., et al, 2018[48]. The excellent use of plant mediated silver nanoparticles in antibacterial as well as anticancer activities has led to a surge in strong interest among different research groups to employ it, reported by Fahimirad, S.,et al, 2018[49].

\section{Conclusion}

In our study silver nanoparticles were biosynthesized by an eco-benign, clean, and useful approach, using leave extract of Thymus vulgaris. UV-visible spectroscopy, FT-IR, AFM, and TEM techniques were utilized to characterize synthesized silver nanoparticles. The UV-Visible spectroscopic results revealed that the NPs synthesized from leave extract of Thymus vulgaris lies within the range of $19-25 \mathrm{~nm}$ and the which was confirmed with the published literature. The morphology and agglomeration of silver nanoparticles using Thymus vulgaris extract were done by atomic force microscopy. Moreover, synthesized nanoparticles have a great antifungal effect. It was concluded that AgNps formed by medicinal plant extracts have remarkable antifungal activity and can be used in various antimicrobial drugs.

\section{Declarations}

\section{Author contributions statement}

F.O.K., E.M.G., H.A., methodology, writing-original draft; A. S. A. E., S.A.E.S, S.W.E., H.E.R, resources, formal analysis; M.B.T., conceptualization, supervision and editing; O.M.A. project administration

\section{Conflicts of interest}

The authors declare no conflict of interest to publish the paper.

\section{Funding}

This study has been funded by the Taif University Researchers Supporting Project number (TURSP-2020/81), 
We are thankful to; (1) The Islamia University Bahawalpur 63100, Pakistan for providing basic facilities for the biogenic synthesis of T/AgNPs. (2) Menoufia University, Shebin El-Kom 32511, Egypt for aiding in biological study. (3) Taif University, Taif 21944, Saudi Arabia for assisting informal analysis of T/AgNPs.

\section{References}

1 Lai C-C, Shih T-P, Ko W-C, Tang H-J \& Hsueh P-R. Severe acute respiratory syndrome coronavirus 2 (SARS-CoV-2) and coronavirus disease-2019 (COVID-19): The epidemic and the challenges. International journal of antimicrobial agents 2020;55:105924.

2 Tängdén T \& Giske C. Global dissemination of extensively drug-resistant carbapenemase-producing E nterobacteriaceae: clinical perspectives on detection, treatment and infection control. Journal of Internal Medicine 2015;277:501-512.

3 Gnat S, Łagowski D \& Nowakiewicz A. Major challenges and perspectives in the diagnostics and treatment of dermatophyte infections. Journal of applied microbiology 2020;129:212-232.

4 Roco MC. The long view of nanotechnology development: the National Nanotechnology Initiative at 10 years. In: Nanotechnology research directions for societal needs in 2020 1-28 (Springer, 2011).

5 Aroob S et al. In situ biogenic synthesis of CuO nanoparticles over graphene oxide: A potential nanohybrid for water treatment. Journal of Environmental Chemical Engineering 2021;9:105590.

6 Misra R, Acharya S \& Sahoo SK. Cancer nanotechnology: application of nanotechnology in cancer therapy. Drug discovery today 2010;15:842-850.

7 Ahmad F, Taj MB, Ramzan M, Raheel A, Shabbir S, Imran M \& Iqbal HM. Flacourtia indica based biogenic nanoparticles: development, characterization, and bioactivity against wound associated pathogens. Materials Research Express 2020;7:015026.

8 Ahmad F, Taj MB, Ramzan M, Ali H, Ali A, Adeel M, Iqbal HM \& Imran M. One-pot synthesis and characterization of in-house engineered silver nanoparticles from Flacourtia jangomas fruit extract with effective antibacterial profiles. Journal of Nanostructure in Chemistry 2021;11:131-141.

9 Salleh A, Naomi R, Utami ND, Mohammad AW, Mahmoudi E, Mustafa N \& Fauzi MB. The potential of silver nanoparticles for antiviral and antibacterial applications: a mechanism of action. Nanomaterials 2020;10:1566.

10 Taj MB et al. Bioconjugate synthesis, phytochemical analysis, and optical activity of NiFe 204 nanoparticles for the removal of ciprofloxacin and Congo red from water. Scientific reports 2021;11:1-19.

11 Singh A, Gautam PK, Verma A, Singh V, Shivapriya PM, Shivalkar S, Sahoo AK \& Samanta SK. Green synthesis of metallic nanoparticles as effective alternatives to treat antibiotics resistant bacterial infections: A review. Biotechnology Reports 2020;25:e00427.

12 Javed H, Tabassum S, Erum S, Murtaza I, Muhammad A, Amin F \& Nisar MF. Screening and characterization of selected drugs having antibacterial potential. Pakistan journal of pharmaceutical sciences 2018;31.

13 Jafri $\mathrm{H} \&$ Ahmad I. Thymus vulgaris essential oil and thymol inhibit biofilms and interact synergistically with antifungal drugs against drug resistant strains of Candida albicans and Candida tropicalis. Journal de mycologie Medicale 2020;30:100911.

14 Vázquez-Sánchez D, Galvão JA, Ambrosio CM, Gloria EM \& Oetterer M. Single and binary applications of essential oils effectively control Listeria monocytogenes biofilms. Industrial Crops and Products 2018;121:452-460.

15 Mehrabyan A \& Redfern S. Medicinal plants and their uses and benefits with reference to small farmers in Armenia.

16 El-Sayed SM \& El-Sayed HS. Antimicrobial nanoemulsion formulation based on thyme (Thymus vulgaris) essential oil for UF labneh preservation. Journal of Materials Research and Technology 2021;10:1029-1041.

17 Aljabeili HS, Barakat H \& Abdel-Rahman HA. Chemical composition, antibacterial and antioxidant activities of Thyme essential oil (Thymus vulgaris). Food and Nutrition Sciences 2018;9:433.

18 de Oliveira JR, Figueira LW, Sper FL, Meccatti VM, Camargo SEA \& de Oliveira LD. Thymus vulgaris L. and thymol assist murine macrophages (RAW 264.7) in the control of in vitro infections by Staphylococcus aureus, Pseudomonas aeruginosa, and Candida albicans. Immunologic research 2017;65:932-943.

19 Cavalheiro M \& Teixeira MC. Candida biofilms: threats, challenges, and promising strategies. Frontiers in medicine 2018;5:28.

20 Sardi J, Scorzoni L, Bernardi T, Fusco-Almeida A \& Giannini MM. Candida species: current epidemiology, pathogenicity, biofilm formation, natural antifungal products and new therapeutic options. Journal of medical microbiology 2013;62:10-24.

Page $12 / 20$ 
21 Mishra N, Prasad T, Sharma N, Payasi A, Prasad R, Gupta D \& Singh R. Pathogenicity and drug resistance in Candida albicans and other yeast species. Acta microbiologica et immunologica Hungarica 2007;54:201-235.

22 Kong EF, Tsui C, Kucharíková S, Andes D, Van Dijck P \& Jabra-Rizk MA. Commensal protection of Staphylococcus aureus against antimicrobials by Candida albicans biofilm matrix. MBio 2016;7:e01365-01316.

23 Ashar A et al. Integrated hydrothermal assisted green synthesis of ZnO nano discs and their water purification efficiency together with antimicrobial activity. Journal of Materials Research and Technology 2021;15:6901-6917.

24 Tsang PW, Bandara HM \& Fong WP. Purpurin suppresses Candida albicans biofilm formation and hyphal development. PLoS One 2012;7:e50866.

25 Luo G, Ibrahim AS, Spellberg B, Nobile CJ, Mitchell AP \& Fu Y. Candida albicans Hyr1p confers resistance to neutrophil killing and is a potential vaccine target. J Infect Dis 2010;201:1718-1728.

26 Sikora M, Dabkowska M, Swoboda-Kopec E, Jarzynka S, Netsvyetayeva I, Jaworska-Zaremba M, Pertkiewicz M \& Mlynarczyk G. Differences in proteolytic activity and gene profiles of fungal strains isolated from the total parenteral nutrition patients. Folia Microbiol (Praha) 2011;56:143-148.

27 Song JY \& Kim BS. Rapid biological synthesis of silver nanoparticles using plant leaf extracts. Bioprocess and biosystems engineering 2009;32:7984.

28 Njagi EC, Huang H, Stafford L, Genuino H, Galindo HM, Collins JB, Hoag GE \& Suib SL. Biosynthesis of iron and silver nanoparticles at room temperature using aqueous sorghum bran extracts. Langmuir 2011;27:264-271.

29 Zhang W, Qiao X \& Chen J. Synthesis and characterization of silver nanoparticles in AOT microemulsion system. Chemical physics 2006;330:495500.

30 Wang X \& Bunkers GJ. Potent heterologous antifungal proteins from cheeseweed (Malva parviflora). Biochemical and biophysical research communications 2000;279:669-673.

31 He S, Zhang Y, Guo Z \& Gu N. Biological synthesis of gold nanowires using extract of Rhodopseudomonas capsulata. Biotechnology Progress 2008;24:476-480.

32 Zayed MF, Eisa WH \& Shabaka A. Malva parviflora extract assisted green synthesis of silver nanoparticles. Spectrochimica Acta Part A: Molecular and Biomolecular Spectroscopy 2012;98:423-428.

33 Basavaraja S, Balaji S, Lagashetty A, Rajasab A \& Venkataraman A. Extracellular biosynthesis of silver nanoparticles using the fungus Fusarium semitectum. Materials Research Bulletin 2008;43:1164-1170.

34 Ji Y, Yang X, Ji Z, Zhu L, Ma N, Chen D, Jia X, Tang J \& Cao Y. DFT-calculated IR spectrum amide I, II, and III band contributions of N-methylacetamide fine components. ACS omega 2020;5:8572-8578.

35 Brilhante RS et al. Yeasts from Macrobrachium amazonicum: a focus on antifungal susceptibility and virulence factors of Candida spp. FEMS microbiology ecology 2011;76:268-277.

36 Ciurea CN, Kosovski I-B, Mare AD, Toma F, Pintea-Simon IA \& Man A. Candida and Candidiasis-Opportunism Versus Pathogenicity: A Review of the Virulence Traits. Microorganisms 2020;8:857.

37 Padhi S \& Behera A. Silver-based nanostructures as antifungal agents: Mechanisms and applications. In: Silver Nanomaterials for Agri-Food Applications 17-38 (Elsevier, 2021).

38 Pemán J, Ruiz-Gaitán A, García-Vidal C, Salavert M, Ramírez P, Puchades F, García-Hita M, Alastruey-Izquierdo A \& Quindós G. Fungal co-infection in COVID-19 patients: Should we be concerned? Revista iberoamericana de micologia 2020;37:41-46.

39 Fan Y, He H, Dong Y \& Pan H. Hyphae-specific genes HGC1, ALS3, HWP1, and ECE1 and relevant signaling pathways in Candida albicans. Mycopathologia 2013;176:329-335.

40 Pentland DR, Piper-Brown E, Muhlschlegel FA \& Gourlay CW. Ras signalling in pathogenic yeasts. Microb Cell 2017;5:63-73.

41 Deorukhkar SC, Saini S \& Mathew S. Virulence Factors Contributing to Pathogenicity of Candida tropicalis and Its Antifungal Susceptibility Profile. Int J Microbiol 2014;2014:456878.

42 Aldardeer NF, Albar H, Al-Attas M, Eldali A, Qutub M, Hassanien A \& Alraddadi B. Antifungal resistance in patients with Candidaemia: a retrospective cohort study. BMC Infect Dis 2020;20:55. 
43 Shah DN, Yau R, Lasco TM, Weston J, Salazar M, Palmer HR \& Garey KW. Impact of prior inappropriate fluconazole dosing on isolation of fluconazole-nonsusceptible Candida species in hospitalized patients with candidemia. Antimicrob Agents Chemother 2012;56:3239-3243.

44 Garnacho-Montero J, Diaz-Martin A, Garcia-Cabrera E, Ruiz Perez de Pipaon M, Hernandez-Caballero C, Aznar-Martin J, Cisneros JM \& Ortiz-Leyba C. Risk factors for fluconazole-resistant candidemia. Antimicrob Agents Chemother 2010;54:3149-3154.

45 Souza AC, Fuchs BB, Pinhati HM, Siqueira RA, Hagen F, Meis JF, Mylonakis E \& Colombo AL. Candida parapsilosis Resistance to Fluconazole: Molecular Mechanisms and In Vivo Impact in Infected Galleria mellonella Larvae. Antimicrob Agents Chemother 2015;59:6581-6587.

46 Vivekshinh Kshtriya, Bharti Koshti \& Gour aN. Green synthesized nanoparticles: Classification,synthesis, characterization, and applications, Comprehensive Analytical Chemistry,. Comprehensive Analytical Chemistry, Elseiver 2021; https://doi.org/10.1016/bs.coac.2020.12.009.

(https://www.sciencedirect.com/science/article/pii/S0166526X20301161).

47 Mohammadi M, Shahisaraee SA, Tavajjohi A, Pournoori N, Muhammadnejad S, Mohammadi SR, Poursalehi R \& Delavari HH. Green synthesis of silver nanoparticles using Zingiber officinale and Thymus vulgaris extracts: characterisation, cell cytotoxicity, and its antifungal activity against Candida albicans in comparison to fluconazole. IET Nanobiotechnol 2019;13:114-119.

48 Anjugam M, Vaseeharan B, Iswarya A, Divya M, Prabhu NM \& Sankaranarayanan K. Biological synthesis of silver nanoparticles using beta-1, 3 glucan binding protein and their antibacterial, antibiofilm and cytotoxic potential. Microb Pathog 2018;115:31-40.

49 Fahimirad S, Ajalloueian F \& Ghorbanpour M. Synthesis and therapeutic potential of silver nanomaterials derived from plant extracts. Ecotoxicol Environ Saf 2019;168:260-278.

\section{Figures}

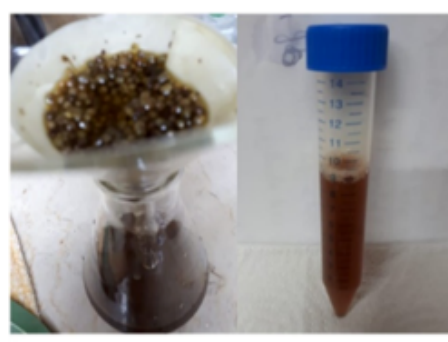

Plant Extract

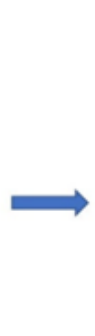

Silver nitrate solution

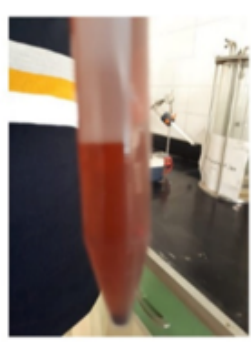

T/AgNPs

Figure 1

Synthesis of T/AgNPs by plant extract 


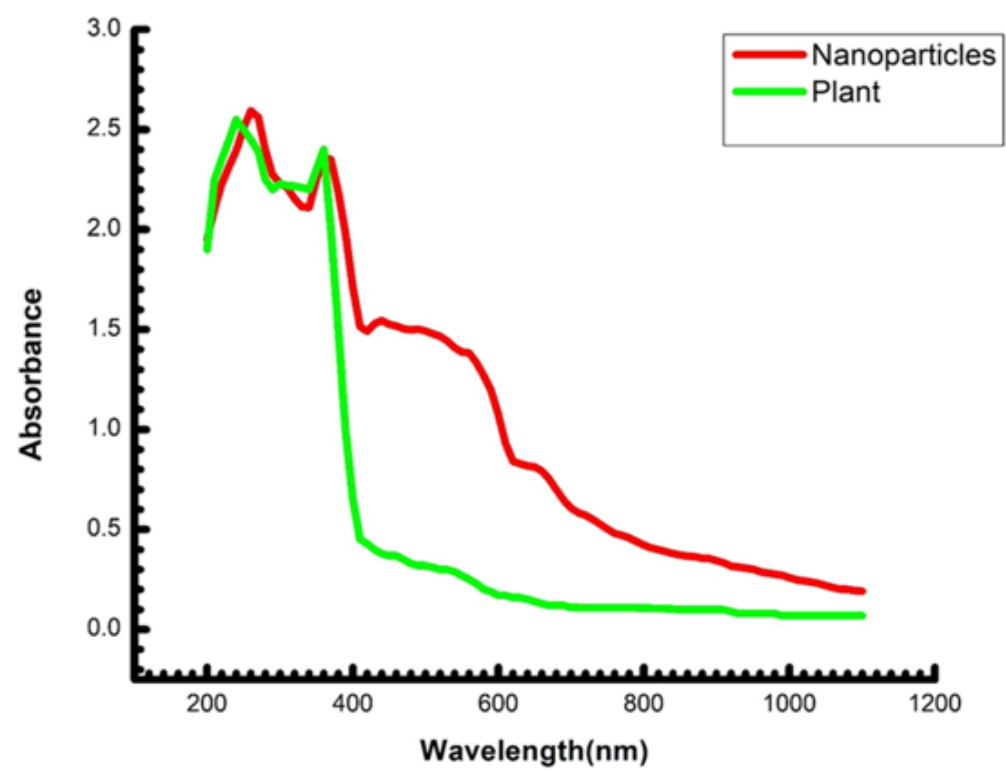

Figure 2

UV-vis spectra of plant extract (green) and silver nanoparticles (red)

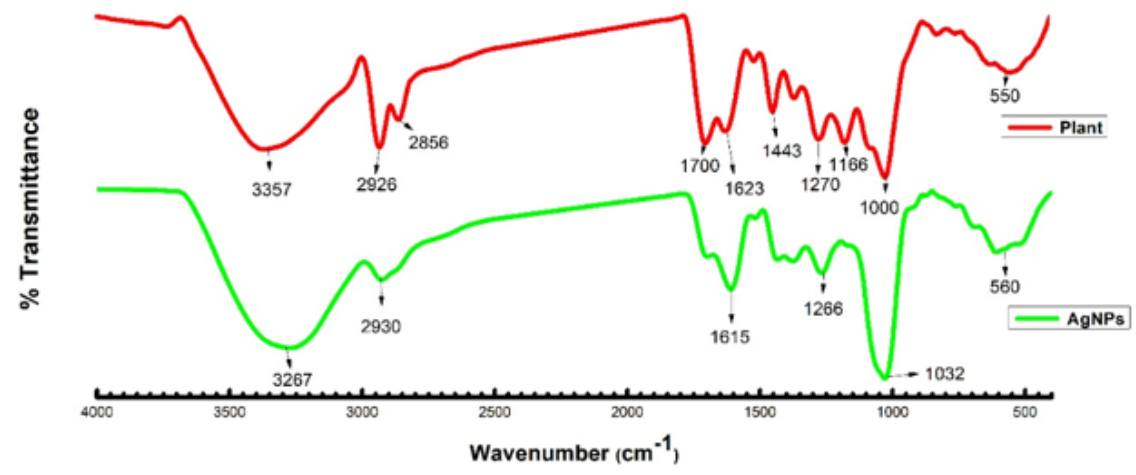

Figure 3

FTIR spectrum of plant extract (red) and silver nanoparticles (green) 


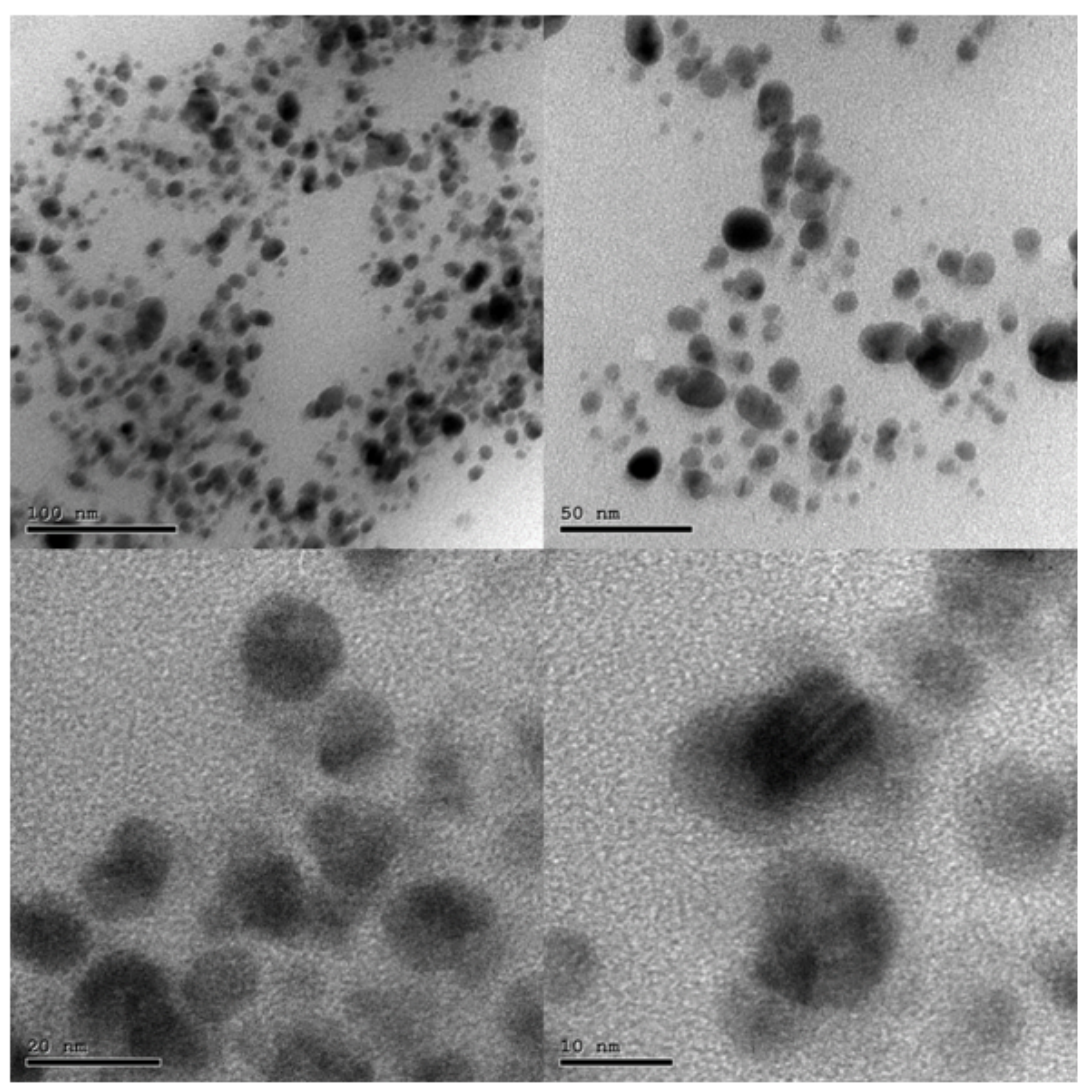

Figure 4

HRTEM image of silver nanoparticles

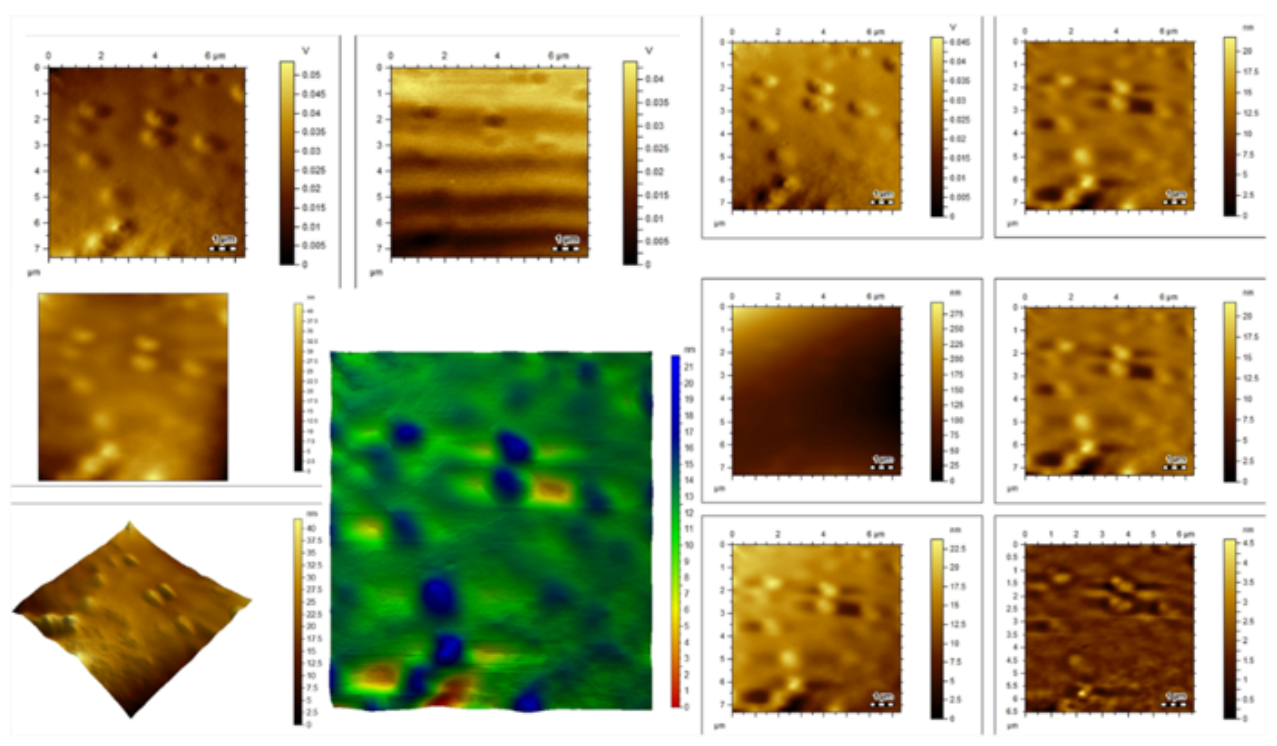

Figure 5

AFM images of Thyme based silver nanoparticles (T/AgNPs) 


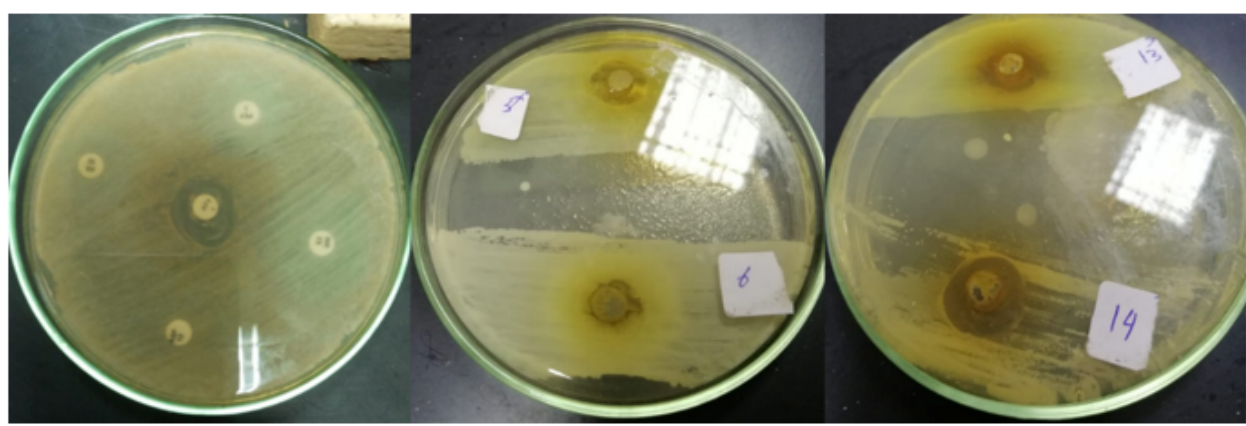

\section{Figure 6}

Selected disks showing the disk diffusion activity of silver nanoparticles.

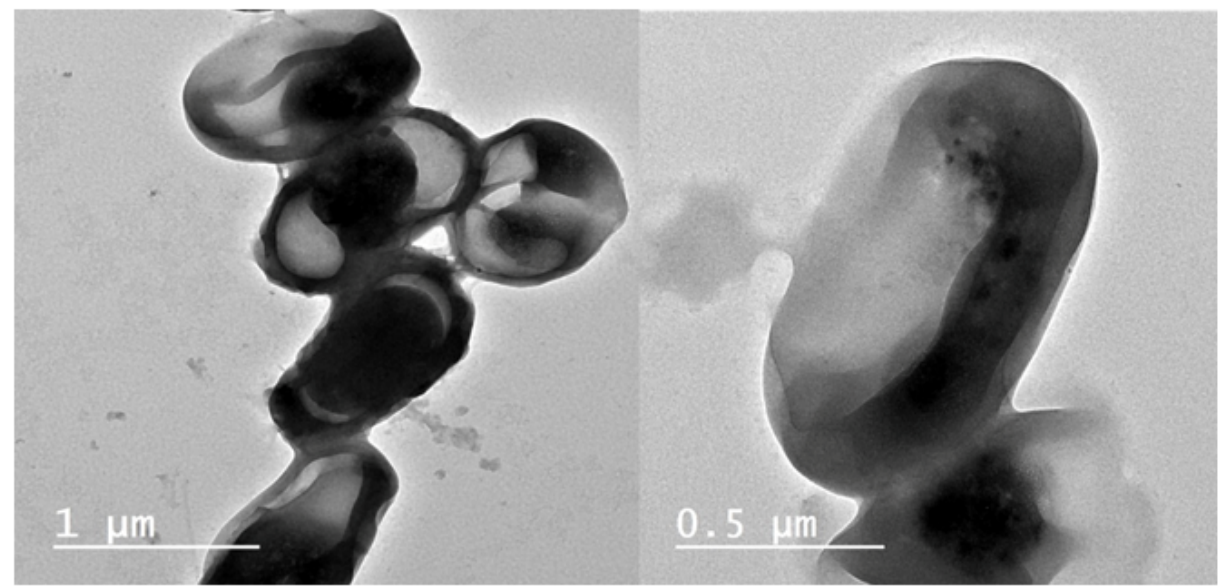

\section{Figure 7}

TEM images of the effect of Thymus vulgaris silver nanoparticles on Candida; destruction of the fungal cell wall with disruption of membrane.

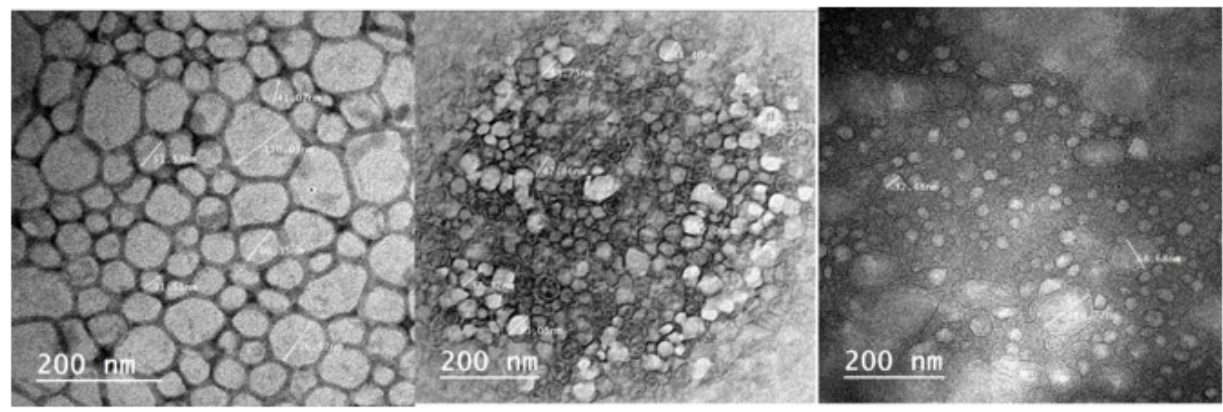

\section{Figure 8}

TEM images of SIL (Solid Immersion Lens) showing shrinkage of Candida albicans isolates after addition of biologically active silver nitrate particles 

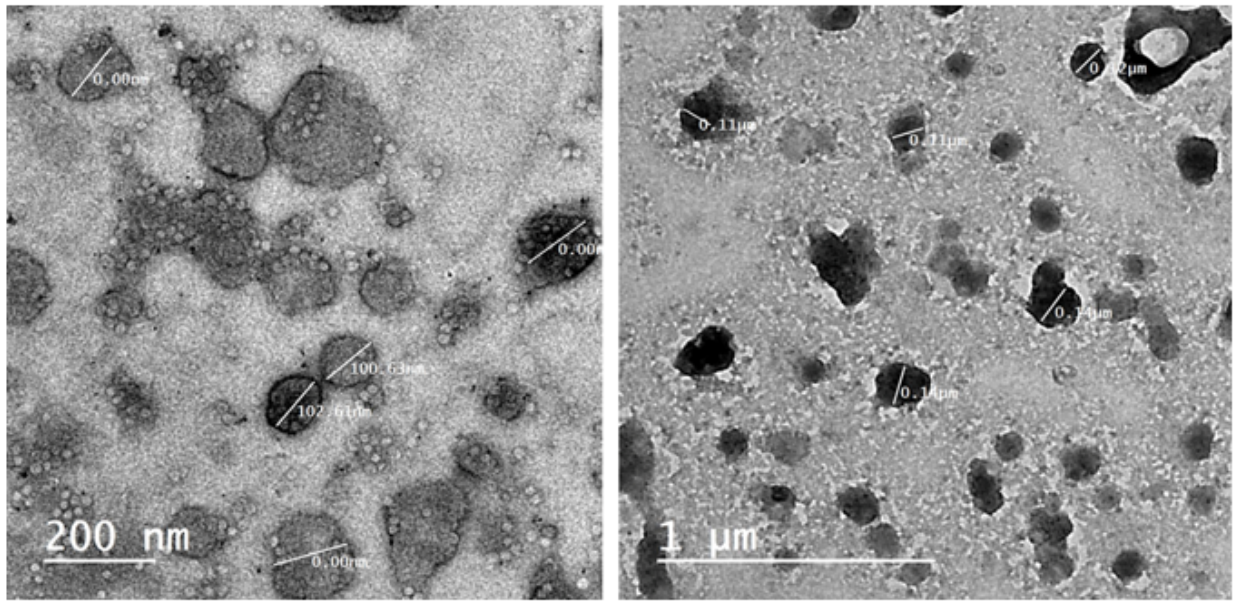

\section{Figure 9}

TEM images showing intracellular biologically active silver nitrate nanoparticles and cellular disruption.

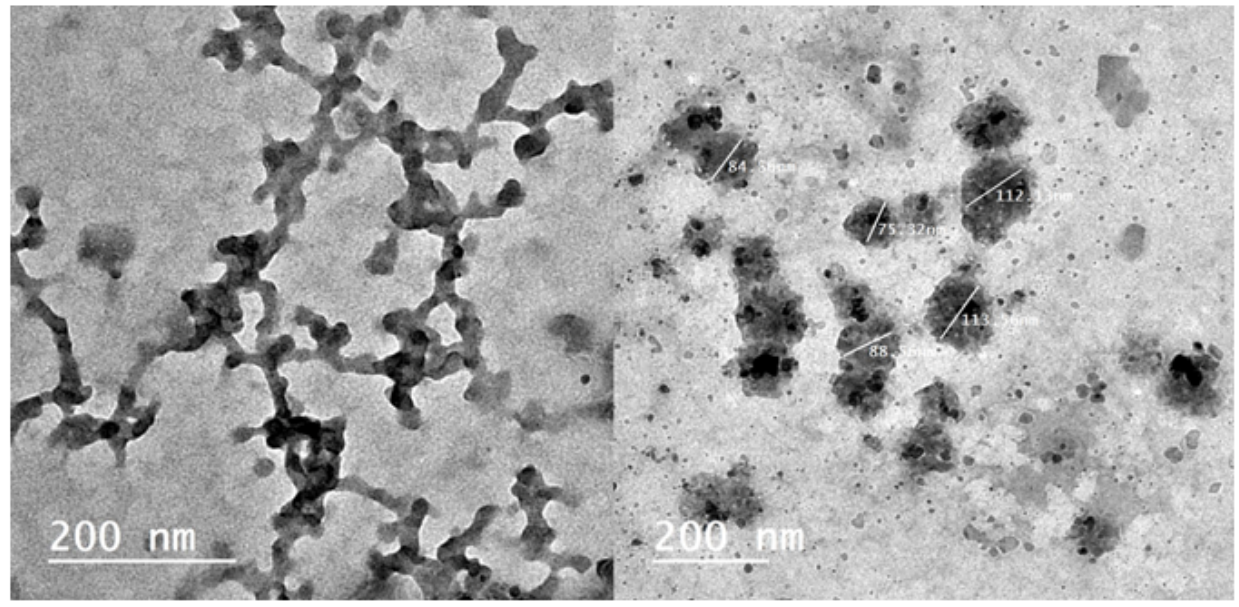

Figure 10

TEM images of the effect of biologically active silver nitrate on Candida albicans isolates.

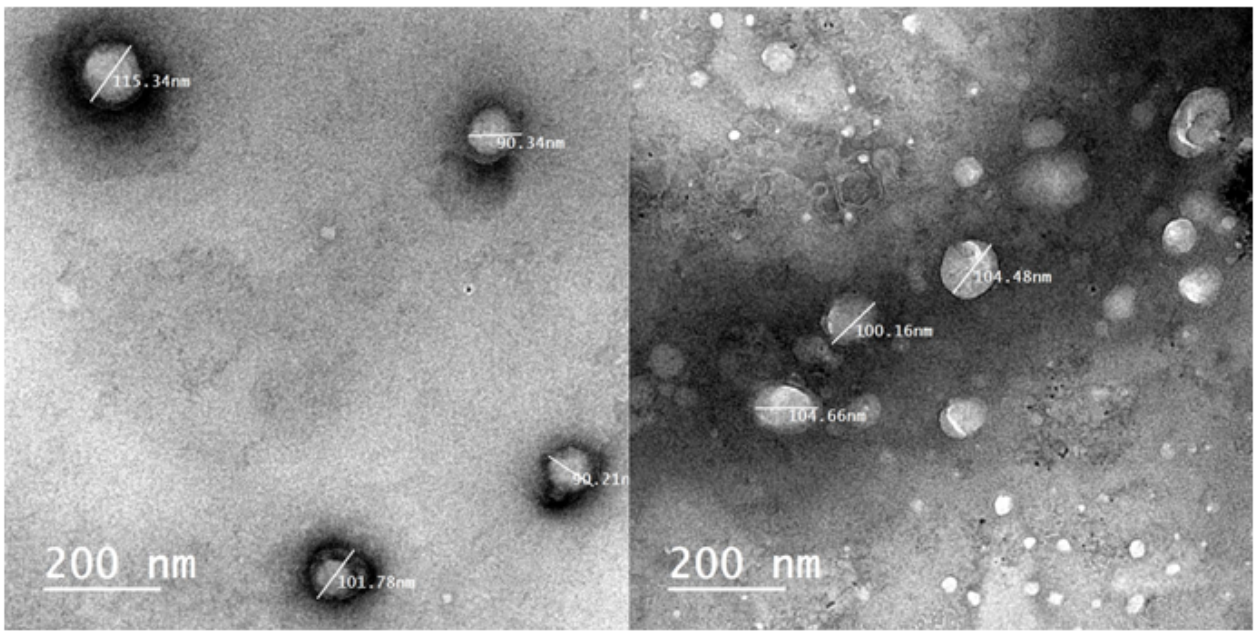

Figure 11

TEM images of intracellular and extracellular distribution of biologically active silver nitrate. 


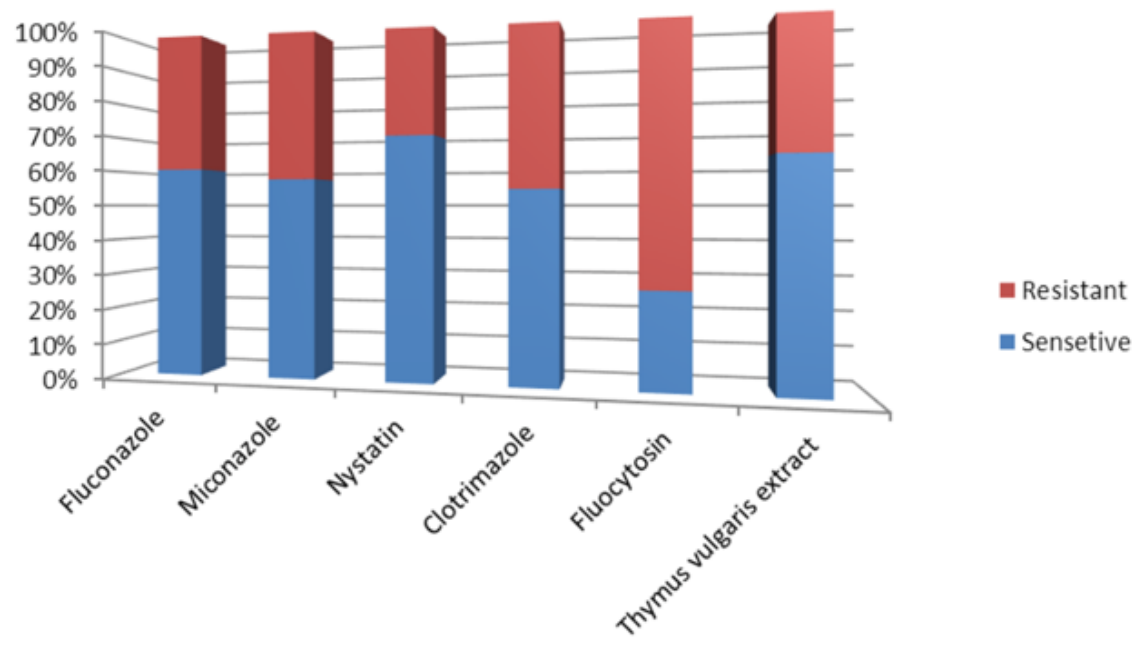

Figure 12

The percentage of resistant isolates to chemical antifungal agents and T/AgNPs

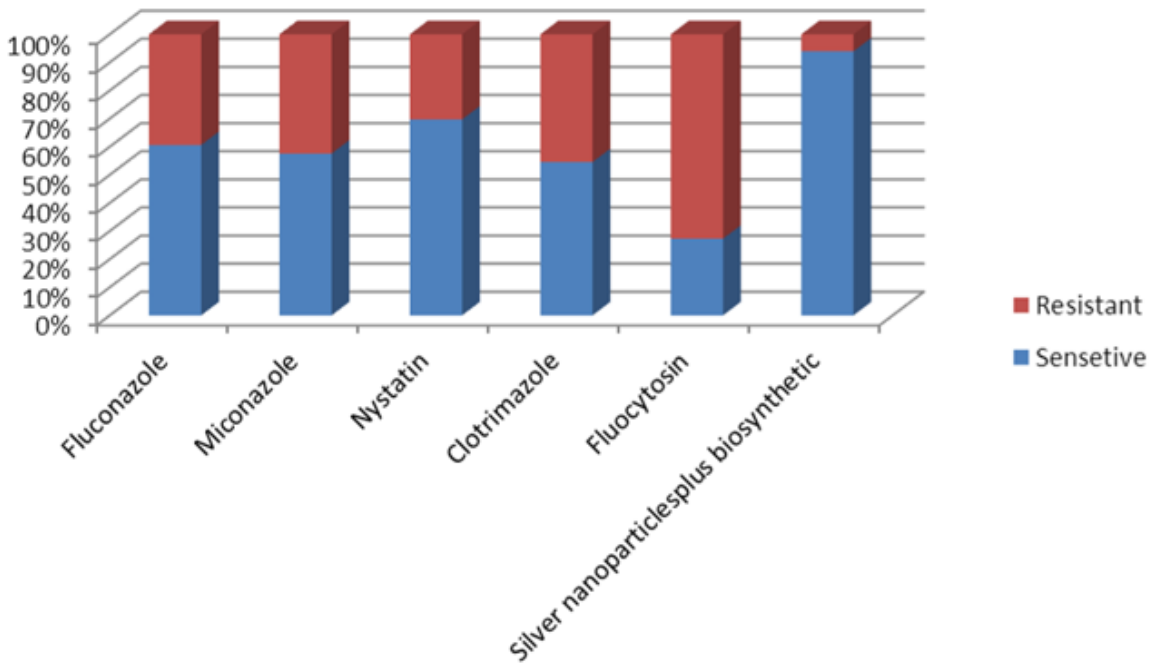

Figure 13

Anti-fungal sensitivity testing of commercial antifungal versus biogenic silver nitrate 

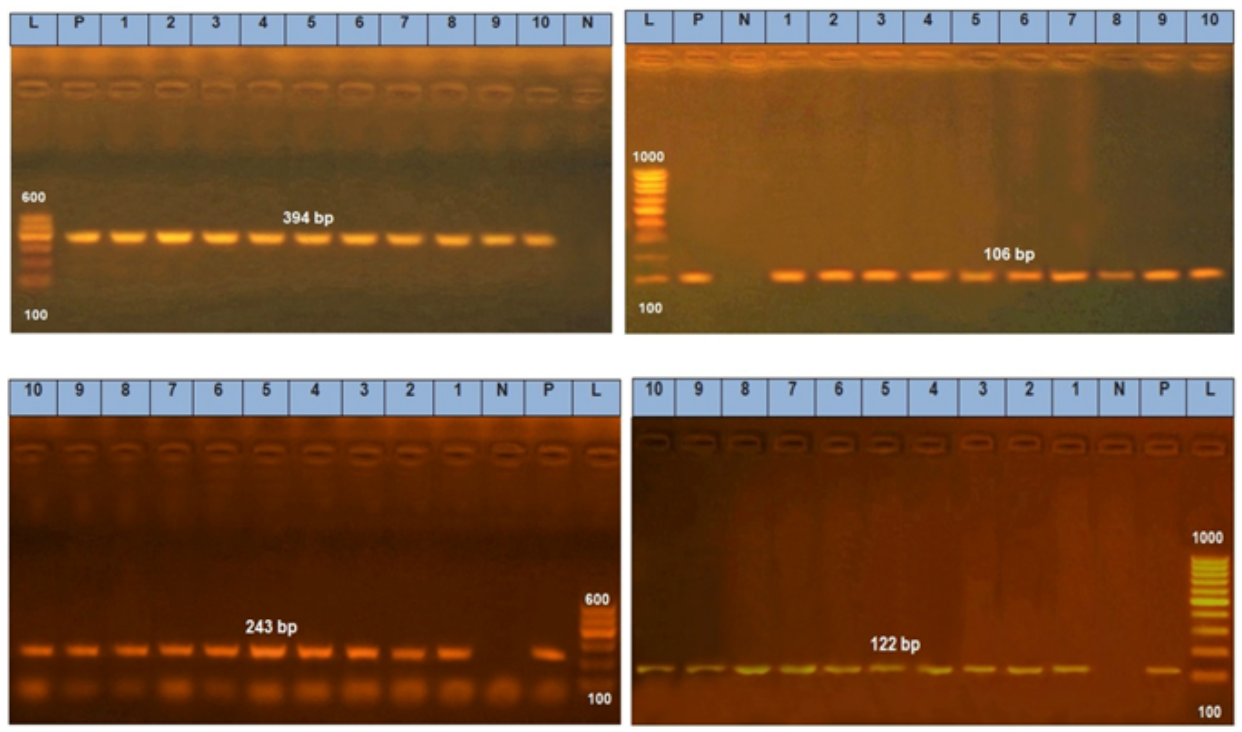

\section{Figure 14}

Gel electrophoresis of Candida virulence genes, Secreted Aspartic Protease gene (SAP4) was detected at 394 bp, RAS1 was detected at 106 bp, HyphalAssociated Adhesin (HYR1) gene was detected at 243 bp and agglutinin-like sequence gene (ALS3) was detected at 122 bp 